\title{
An Analysis of Maxillofacial Injuries due to Assault from Non Projectile Weapons in Patients Reporting to the Tertiary Care Hospital in Port Harcourt
}

\section{BO Akinbami* and SE Udeabor}

Department of Oral and Maxillofacial Surgery, University of Port Harcourt Teaching Hospital, Nigeria

\begin{abstract}
Background: Majority of maxillofacial injuries in Port Harcourt, Nigeria is caused by road traffic accidents $(57.1 \%)$, assaults $(17.6 \%)$, gunshots $(14.3 \%)$ and falls $(9.9 \%)$. However, many reports on maxillofacial trauma have not focused specifically on assault and from our study, some of the injuries were severe based on tissue involved, tissue loss and bone involvement, the purpose of this study was to document our experience in the pattern and management of maxillofacial injuries due to assault from non projectiles in our center.
\end{abstract}

Method: Patients' demographics, site and type of injury, tissue involved as well as presence of associated injuries. The objects that were used to inflict the injuries were documented. Soft tissue injuries were classified as either contusions alone or contusions with laceration, avulsions or degloving injuries. The investigations and treatment done, and outcome of treatment were also documented. The treatment outcome was based on esthetic appearance of the scars and patients satisfaction.

Result: Of the 31 patients, 21 had detailed information for analysis, 14(66.7\%) were males and females were $7(33.3 \%), 8(38.1 \%)$ had both soft and hard tissue injuries while 13(61.9) cases had only soft tissue injuries. Age range was between 14 years and 55 years with mean (SD) of 27.9(9.1) years. There was associated head injury in $2(9.5 \%)$ cases. Domestic violence between spouses and family members accounted for $4(19 \%)$ cases, child battering for $1(4.8 \%)$ case and the others were due conflict between neighbors or friends

Conclusion: Intervention strategies should be targeted at the youths and adult without gainful employment in order to minimize aggression and violence.

Keywords: Assault; Impact; Facial; Injury

\section{Introduction}

Interpersonal violence/ assault which have been established as the commonest etiology of maxillofacial injuries in the developed countries are now increasingly becoming a major cause in Nigeria and underlying factors seems to be the same or a little different [1]. Such violence are now escalating as a result of the declining socioeconomic status and unemployment rates that has become prevalent in our society [2] Unfortunately, despite most of the programs and policies of successive governments to alleviate poverty, many citizens and particularly the youths and graduates still remain unemployed. Also because of the low profit margin of many private companies, quite a number of the previously employed are losing their jobs as a result of downsizing or folding up of many companies. In addition, the present insecurity in the nation, insurgence and terrorist attacks in some northern states and kidnapping experiences in many parts of the country has not helped to improve the influx of foreign investors into the country. This myriad of economic issues has obviously led to changes in the psychosocial status of many, tending towards imbalance, uncontrollable temper and aggression in the homes and society with consequent result to misunderstanding, quarrel and fighting at the slightest provocation. When injuries are inflicted on the face, it further compounds the psychological trauma to the victims. A lot of articles abound in the Nigerian literature but not many have focused on this etiology of maxillofacial trauma [3-6] and none exist from this south -south region of the country, we also noticed severity of some injuries that presented. Therefore, the aim of this study was to document our experience in the pattern and management of maxillofacial injuries due to assault from non projectile weapons seen in our center.

\section{Patients and Method}

The study was a prospective study. All consecutive patients with maxillofacial injuries due to assault from non projectile weapons that presented to the accident and emergency as well as the oral and maxillofacial surgery clinic of the University of Port Harcourt teaching hospital between May 2008 and June 2013 were included in the study. We have separated cases of assaults due to gunshot injuries due to the peculiar wound characteristics and management of such cases as well as the gross morbidity and mortality effects, patients with gunshot injuries were excluded from this study because we are reporting such in another study. Informed consent was obtained from the patients included in the study and approval was obtained from the ethics and research committee of the hospital to carry out the study. Information regarding patients' demographics, site and type of injury, tissue involved, objects that were used to inflict the injuries, presence of associated injuries as well as family/social histories were obtained in a case report format. Soft tissue injuries were classified as either contusions alone or contusions with laceration, avulsions or degloving injuries. The investigations

*Corresponding author: Babatunde Akinbami, Department of Oral and Maxillofacial Surgery, University of Port Harcourt Teaching Hospital, Nigeria, E-mail: akinbamzy3@yahoo.com

Received September 03, 2013; Accepted September 24, 2013; Published September 24, 2013

Citation: Akinbami BO, Udeabor SE (2013) An Analysis of Maxillofacial Injuries due to Assault from Non Projectile Weapons in Patients Reporting to the Tertiary Care Hospital in Port Harcourt. J Trauma Treat 2: 178. doi:10.4172/2167-1222.1000178

Copyright: (c) 2013 Akinbami BO, et al. This is an open-access article distributed under the terms of the Creative Commons Attribution License, which permits unrestricted use, distribution, and reproduction in any medium, provided the original author and source are credited. 
Citation: Akinbami BO, Udeabor SE (2013) An Analysis of Maxillofacial Injuries due to Assault from Non Projectile Weapons in Patients Reporting to the Tertiary Care Hospital in Port Harcourt. J Trauma Treat 2: 178. doi:10.4172/2167-1222.1000178

Page 2 of 3

done such as CT scan and plain radiology (posterior-anterior and oblique lateral views for the lower jaw, occipitomental and true lateral views of the skull for the midface), treatment done and outcome of treatment were also documented. Patients were categorized into two groups; those that sustained soft and hard tissue injuries and those with only soft tissue injuries. The treatment outcome was based on esthetic appearance of the scars and patients satisfaction. Data obtained was analyzed with SPSS version 16 (Illinois, Chicago) and expressed as simple frequencies and percentages.

\section{Results}

A total of 31 patients presented with maxillofacial injuries due to assault from non-projectile weapons within this period of study out of 135 patients with craniofacial trauma, but 10 of these, refused management due to financial constrains. 14(66.7\%) were males and females were $7(33.3 \%)$ (Table 1). Age range was between 14 years and 55years with mean (SD) of 27.9(9.1) years. There was associated head injury in $2(9.5 \%)$ cases. Twelve $(57.1 \%)$ of the patients were married and $17(81.0 \%)$ were self employed with insufficient income.

Although, there was no significant relationship between injury severity and cause of assault, but females were mostly victims of domestic violence and their injuries were from the fist of their husbands. Also, patients with soft tissue injuries had shorter hospital stay than those with both hard and soft tissue trauma. None of our patients gave any history of use of alcohol or psychoactive drugs and therefore no relationship with severity of injury. Domestic violence between spouses and family members accounted for $4(19.0 \%)$ cases, child battering for $1(4.8 \%)$ case and the others were due to conflict between neighbors or friends. Object in form of knife, bottle, plank was used to inflict the injury in $14(66.7 \%)$ patients while $6(28.6 \%)$ sustained injuries from the fist and 1(4.8\%) from human bite. There was no case of assault from animal attack (Figure 1).

Eight (38.1\%) had both soft and hard tissue injuries while 13(61.9) cases had only soft tissue injuries (Table 2). All the 21 patients sustained bruise/contusion injuries characterized by swelling with or without ecchymosis. There was $1(4.8 \%)$ case of complete avulsion of the vermillion of the lower lip due to human bite from a rival woman and $1(4.8 \%)$ case of degloving injury also to the lower lip from knife. $14(66.7 \%)$ patients had laceration in addition to the contusion. CT scan was done in $1(4.8 \%)$ to confirm extent of frontal bone and plain $\mathrm{x}$-rays also confirmed fractures in other cases with bone fractures.

Eighteen $(85.7 \%)$ of the patients were admitted with an average hospital stay of 10 days. For cases with fractures of the mandible, they were treated with closed reduction and Intermaxillary Fixation (IMF) for 6 weeks. One of the cases with frontal bone fracture needed no reduction or fixation and was managed as a closed linear undisplaced fracture. The second case needed reduction of the depressed frontal bone (anterior table of the right sinus) without fixation (Figures 2 and 3 ). The nasal and maxillary fractures were also not displaced, and conservative therapy with drugs was sufficient.

All lacerations were sutured primarily and undermining when necessary, while contusions were managed by conservative treatment. One of the cases with avulsed lower vermillion had reconstruction with skin of the lower lip and undermining of the mucosa, while another case of incomplete avulsion (degloving) had a successful repair of the lip. There were no cases of death in this study. Outcome was successful and satisfactory to all the patients.

\section{Discussion}

The most common cause of oral and maxillofacial injuries in Nigeria still remains road traffic accidents, $[5,6]$ but injuries from other causes are gradually increasing. The prevalence of assault in our study was $23.0 \%$; this was comparable to the study of Obimakinde [7] from

\begin{tabular}{|c|c|c|c|}
\hline Age & Male N(\%) & Female N(\%) & Total N(\%) \\
\hline $10-19 y r s$ & $1(4.8)$ & $1(4.8)$ & $2(9.6)$ \\
\hline $20-29 y r s$ & $7(33.3)$ & $6(28.6)$ & $13(61.9)$ \\
\hline $30-39 y r s$ & $4(19.0)$ & $0(0)$ & $4(19.0)$ \\
\hline $40-49 y r s$ & $1(4.8)$ & $0(0)$ & $1(4.8)$ \\
\hline $50-59 y r s$ & $1(4.8)$ & $0(0)$ & $1(4.8)$ \\
\hline Total & $\mathbf{1 4}(63.7)$ & $\mathbf{7 ( 3 3 . 4 )}$ & $\mathbf{2 1 ( 1 0 0 )}$ \\
\hline
\end{tabular}

Table 1: Distribution of Age and gender of Twenty-one (21) Patients with Maxillofacial trauma from assault.

\section{Forms of Assault}

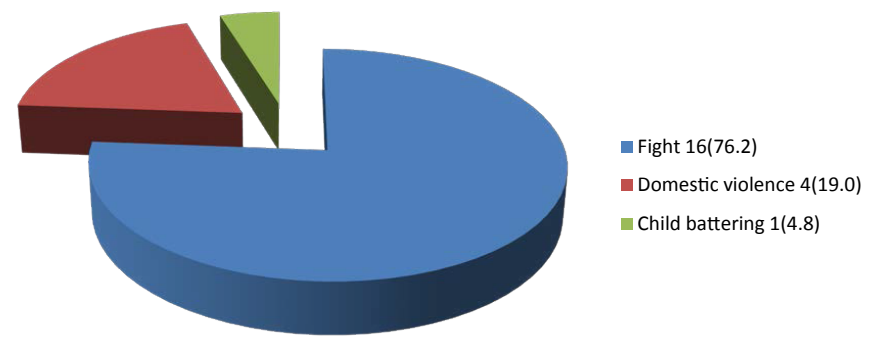

Figure 1: Pie Chart: Distribution of Twenty one (21) patients based on the forms of assault.

\begin{tabular}{|c|c|c|c|}
\hline Hard tissue & $\mathbf{N}(\%)$ & Soft tissue & $\mathbf{N}(\%)$ \\
\hline Frontal bone & $2(9.5)$ & Ear & $1(4.8)$ \\
\hline Nasal bone & $1(4.8)$ & Scalp & $9(42.9)$ \\
\hline Mandible & $2(9.5)$ & Eye & $3(14.3)$ \\
\hline Maxilla & $1(4.8)$ & Salivary gland & $1(4.8)$ \\
\hline Supraorbital & $1(4.8)$ & Lip & $3(14.3)$ \\
\hline Glabella & $1(4.8)$ & Nose & $4(19.0)$ \\
\hline Zygoma & $0(0)$ & Cheek & $1(4.8)$ \\
\hline Total & $\mathbf{8 ( 3 8 . 1 )}$ & & $\mathbf{2 1 ( 1 0 0 )}$ \\
\hline
\end{tabular}

Table 2: Distribution of hard and soft tissue injuries sustained by Twenty-one (21) Patients with Maxillofacial trauma from assault.

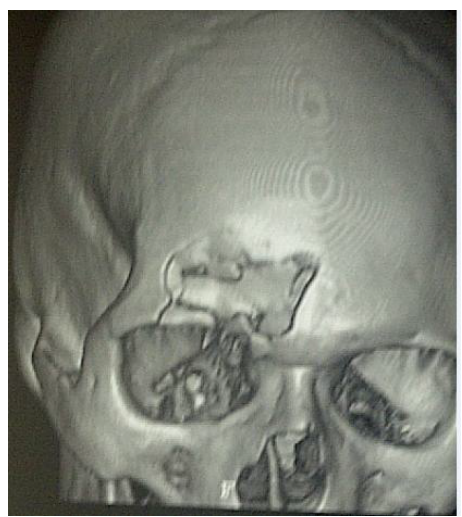

Figure 2: D CT Scan reconstruction of a patient with frontal bone fracture. 


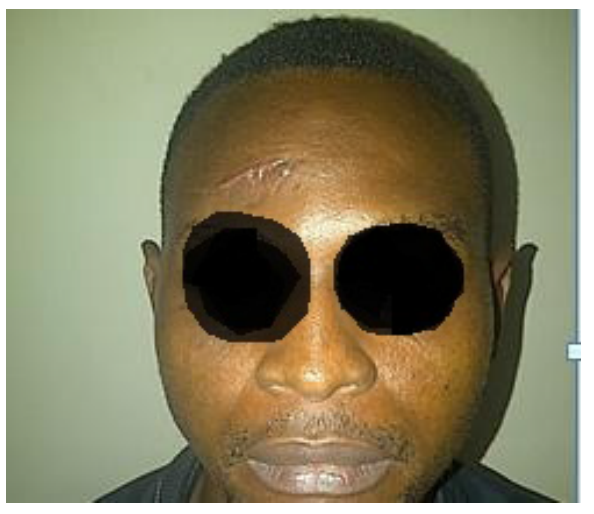

Figure 3: Photograph of the patient with frontal bone fracture.

the southwest where assault constituted about $21.8 \%$ but in contrast to that of Olasoji [8] who reported a prevalence of $57.1 \%$ from the north eastern part of the country. The higher figure from this part of the country was mainly due to the lifestyle of the people in the region. The animals are reared and moved through long distances destroying cash crops, leading to clashes between farmers and cattlemen. Recently, there are also changing trends in India with assault taking the lead.

The peak age incidence of 21-30 years was found in our study and this corroborates the literature, [7-9] reason is that people in this age group seeks an improved livelihood and are likely to be involved in violence from frustration when such standards of living are farfetched. Also, we found a higher male preponderance in support of other studies; [7-10] but for domestic violence, in this study some female victims were assaulted by their spouse or the girlfriend. Low socioeconomic status and emotional stress from unemployment result in aggression by men who react by assaulting their wives. Alcohol consumption and its influence on domestic/interpersonal violence have also been documented in the literature, although this was not found in this study as none of our patients declared any use of alcohol or psychoactive drugs $[7,9]$.

As documented by other studies, [7,11,12] contusion was the most common soft tissue injury in our study and was found in all patients. This is due to the fact that regardless of the object used for assault, there is always an accompanied inflammation and swelling of the subcutaneous tissue injury. But when there is loss of skin integrity in form of laceration or avulsion, the swelling tends to reduce. In our study, facial lacerations were caused by sharp objects such as knife, planks and broken bottles while avulsion from human bite was also reported. The case with salivary gland involvement presented with a complication of sialocele which was treated with pressure pack, aspiration and re routing with internal cannula while the eye injured had suturing of the lacerated cornea and there was no complication of corneal opacities.

Scalp injuries were the commonest site for soft tissue; likewise we recorded cases of frontal bone fractures and associated head injuries as well as midfacial and lower jaw injuries in this study. Any force more than 50 times the force of gravity will fracture a bone; fractures to most parts of facial bones are severe injuries from such high impact [13]. Dentoalveolar fracture constituted the highest figures in other studies $[7,14,15]$ In our study, mandibular fractures were sustained over $9 \%$ of cases and were treated with closed reduction and intermaxillary fixation while the nasal fracture was reduced with Walsham forceps without need for fixation. Where there is avulsion of anterior table, calvarium or iliac bone grafts should be used to prevent frontal hollowing [16].

We recommend that every youth and unemployed must be duly targeted from the grassroots and at the three levels of government, education and/or vocational skills must be made compulsory and government/private or corporate partnership schemes should be established and well monitored. Reforms in the power sector and continuous orientation of engaged youths on effects of insecurity will also help to attract investors and create employment. Population control is becoming increasingly necessary and purposeful legislation against corruption and violence, as well as improved prison reformations should be embarked upon with the goal of rehabilitation.

In conclusion, we documented cases of assault with over $50 \%$ who sustained severe injuries to the soft and hard tissues especially to the mandible, frontal bone, brain, lips and eyes. Assault is a major etiology in the management of trauma by the maxillofacial surgeons and strategies to minimize incidences of these avoidable injuries should be instituted.

\section{References}

1. Telfer MR, Jones GM, Shepherd JP (1991) Trends in the aetiology of maxillofacial fractures in the United Kingdom (1977-1987). Br J Oral Maxillofac Surg 29: 250-255

2. Adeyemo $\mathrm{WL}$, Ladeinde $\mathrm{AL}$, Ogunlewe MO, James $\mathrm{O}$ (2005) Trends and characteristics of oral and maxillofacial injuries in Nigeria: a review of the literature. Head Face Med 1: 7

3. Ugboko VI, Odusanya SA, Fagade OO (1998) Maxillofacial fractures in a semiurban Nigerian teaching hospital. A review of 442 cases. Int J Oral Maxillofac Surg 27: 286-289.

4. Olasoji HO, Tahir A, Arotiba GT (2002) Changing picture of facial fractures in northern Nigeria. Br J Oral Maxillofac Surg 40: 140-143.

5. Fasola AO, Nyako EA, Obiechina AE, Arotiba JT (2003) Trends in the characteristics of maxillofacial fractures in Nigeria. J Oral Maxillofac Surg 61 1140-1143.

6. Fasola AO, Obiechina AE, Arotiba JT (2001) An audit of midfacial fractures in Ibadan, Nigeria. Afr J Med Med Sci 30: 183-186

7. Obimakinde OS, Okoje VN, Fasola AO (2012) Pattern of Assault-induced Ora and Maxillofacial Injuries in Ado-Ekiti, Nigeria. Niger J Surg 18: 88-91.

8. Olasoji HO (1999) Maxillofacial injuries due to assault in Maiduguri, Nigeria Trop Doct 29: 106-108.

9. Kapoor P, Kalra N (2012) A retrospective analysis of maxillofacial injuries in patients reporting to a tertiary care hospital in East Delhi. Int J Crit IIIn Inj Sci 2: $6-10$.

10. Sastry SM, Sastry CM, Paul BK, Bain L, Champion HR (1995) Leading causes of facial trauma in the major trauma outcome study. Plast Reconstr Surg 95: 196-197.

11. Khan AA (1988) A retrospective study of injuries to the maxillofacial skeleton in Harare, Zimbabwe. Br J Oral Maxillofac Surg 26: 435-439.

12. Le BT, Dierks EJ, Ueeck BA, Homer LD, Potter BF (2001) Maxillofacial injuries associated with domestic violence. J Oral Maxillofac Surg 59: 1277-1283.

13. Akinbami BO (2011) Etiology and Pathophysiology ofmaxillofacial trauma (1stedn), Synopsis of management of maxillofacial trauma Rosedog Publishers, Pittsburg.

14. Gassner R, Bösch R, Tuli T, Emshoff R (1999) Prevalence of dental trauma in 6000 patients with facial injuries: implications for prevention. Oral Surg Oral Med Oral Pathol Oral Radiol Endod 87: 27-33.

15. Gassner R, Tuli T, Hächl O, Rudisch A, Ulmer H (2003) Cranio-maxillofacia trauma: a 10 year review of 9,543 cases with 21,067 injuries. J Craniomaxillofac Surg 31: 51-61.

16. Akadiri OA (2011) Definitive management of fractures of the frontal bone (1stedn), Synopsis of management of maxillofacial trauma Rosedog Publishers: Pittsburg. 